Mycologia, 107(6), 2015, pp. 1151-1171. DOI: 10.3852/15-059

(C) 2015 by The Mycological Society of America, Lawrence, KS 66044-8897

\title{
Cercosporoid diseases of Citrus
}

Feng Huang Institute of Biotechnology, Zhejiang University, Hangzhou 310058, China

J.Z. Groenewald CBS-KNAW Fungal Biodiversity Centre, Uppsalalaan 8, 3584 CT, Utrecht, the Netherlands

Li Zhu Institute of Biotechnology, Zhejiang University, Hangzhou 310058, China

P.W. Crous ${ }^{1}$

CBS-KNAW Fungal Biodiversity Centre, Uppsalalaan 8, 3584 CT, Utrecht, the Netherlands Department of Plant Pathology and Microbiology, Forestry and Agricultural Biotechnology Institute (FABI), University of Pretoria, Pretoria 0002, South Africa Microbiology, Department of Biology, Utrecht University, Padualaan 8, 3584 CH Utrecht, the Netherlands

Hongye $\mathrm{Li}^{1}$

Institute of Biotechnology, Zhejiang University, Hangzhou 310058, China

Abstract: Citrus leaves and fruits exhibiting disease symptoms ranging from greasy spot, yellow spot, small or large brown spot, black dot, and brown dot were sampled from Fujian, Guangdong, Guizhou, Hunan, Jiangxi, Yunnan, Zhejiang provinces and the Guangxi Zhuang Autonomous Region in China. In total 82 isolates representing various cercosporoid genera were isolated from these disease symptoms, which were supplemented with eight Citrus cercosporoid isolates collected from other countries. Based on a morphological and phylogenetic study using sequence data from the nuclear ribosomal DNA's ITS1-5.8S-ITS2 regions (ITS), and partial actin (act), $\beta$-tubulin (tub2), 28S nuclear ribosomal RNA (28S rDNA) and translation elongation factor $1-\alpha$ (tef1) genes, these strains were placed in the following genera: Cercospora, Pallidocercospora, Passalora, Pseudocercospora, Verrucisporota and $\mathrm{Za}$ smidium. All isolates tended to be sterile, except the Zasmidium isolates associated with citrus greasy spotlike symptoms, which subsequently were compared with phylogenetically similar isolates occurring on Citrus and other hosts elsewhere. From these results four Zasmidium species were recognized on Citrus, namely Z. indonesianum on Citrus in Indonesia,

Submitted 25 Jun 2015; accepted for publication 25 Jun 2015.

${ }^{1}$ Corresponding authors. E-mail: p.crous@cbs.knaw.nl, hyli@zju.edu. cn
Z. fructicola and Z. fructigenum on Citrus in China and Z. citri-griseum, which appears to have a wide host range including Acacia, Citrus, Eucalyptus and Musa, as well as a global distribution.

Key words: citrus greasy spot, multigene phylogenetic analyses, Mycosphaerella, Pseudocercospora, Zasmidium

\section{INTRODUCTION}

Several species of cercosporoid fungi have been associated with leaf and fruit spot diseases of Citrus spp. (Pretorius et al. 2003), of which two are regarded as particularly serious. Greasy leaf spot, caused by Zasmidium citri-griseum(sexual morph Mycosphaerella citri) (Sivanesan 1984, Timmer and Gottwald 2000, Braun et al. 2014), and Phaeoramularia fruit and leaf spot, caused by Pseudocercospora angolensis (Seif 2000), which is also of quarantine concern in Europe (Quaedvlieg et al. 2012, Crous et al. 2013).

In former years these genera were treated as asexual morphs of the genus Mycosphaerella (Corlett 1991, Crous et al. 2004b), although recent phylogenetic studies have shown that this complex consists of more than 40 genera and that these asexual morphs represent genera in their own right (Crous et al. 2007, 2009b). Many of these represent important phytopathogenic genera, including Cercospora (Crous et al. 2006, Groenewald et al. 2013), Passalora, Pseudocercospora (Crous et al. 2013), Ramularia (Braun 1995, 1998; Videira et al. 2015), Septoria (Quaedvlieg et al. 2013, Verkley et al. 2013), Zasmidium (Braun et al. 2013, 2014) and Zymoseptoria (Quaedvlieg et al. 2011, Stukenbrock et al. 2012), to name but a few.

Several leaf spot diseases of citrus have been associated with cercosporoid fungi in the past. Greasy leaf spot of citrus originally was associated with Cercosporacitri-grisea in Florida, although the fungus was isolated from brown leaf spot symptoms (Fisher 1961), in contrast to the greasy leaf spots linked to Mycosphaerellacitri (Whiteside 1972). Presently this disease is still a major problem in Florida and has also been reported from many other areas including Mexico, Central America, the Caribbean islands and Egypt (Mondal et al. 2004, Haggag 2012). At the same time similar diseases of citrus have been observed in Argentina, Australia and Japan (Tanaka and Yamada 1952, Marcó and Whiteside 1986, Timmer and Gottwald 2000). A different disease, called citrus pseudo greasy spot was reported from Japan (Koizumi 1986, Furuya et al. 2012). Although Yamada (1956) linked Mycosphaerella horii to citrus leaf spot in this country, the illustration suggests 
it could be a species of Didymella. Fisher (1961) reported Cercospora gigantea from grapefruit leaves in Florida, but an examination of the type specimen suggests this is probably a synonym of Corynespora citricola (Pretorius et al. 2003). Crous and Braun (2003) reported Passalora citricola from leaves of Citrus (origin unknown) and P. citrigena from leaf spots of Citrus sp. occurring in Mexico. Several species of Cercospora, identified as $C$. penzigii, have been associated with leaf spots on a range of Citrus spp. from Algeria, Argentina, Azerbaijan, Bhutan, Caucasus, China, Cuba, Dominican Republic, India, Italy, Japan, Mexico, Papua New Guinea, Senegal, South Africa, Swaziland, USA (FL, MS, TX) and Venezuela (Pretorius et al. 2003). Phylogenetically, however, these isolates appear to represent unresolved species in the C. canescens, C. fagellaris and Cercospora sp. P species complexes (Groenewald et al. 2013).

Citrus represents a significant and rapidly growing global industry. Among all citrus-producing countries, China is regarded as one of the most important centers of origin of Citrus, having a citrus-growing history of more than 4000 y (Deng et al. 2008, Zhou and Ye 2010). Presently citrus represents a significant industry in more than nine provinces, autonomous regions and municipalities in China (Deng et al. 2008). The major cultivars grown here include grapefruit, kumquat, lemon, mandarin, orange, pomelo and tangerine (Deng et al. 2008). All these cultivars suffer from citrus greasy spot, which has been recorded under three different names based on their different occurring symptoms, including greasy spot (Huang 1943, Zhang and Yin 1987), yellow spot (Yan 1984, Jiang et al. 2012) and small brown spot (Zhang and Yin 1987).

In the present study we collected citrus materials with a range of leaf spot symptoms throughout China and supplemented this collection with Citrus isolates collected in other countries. We aimed to characterize and compare the cercosporoid species associated with citrus greasy spot in China and elsewhere with the consolidated species concept introduced by Quaedvlieg et al. (2014). Under this species concept, species are recognized based on the combination of morphological, ecological and phylogenetic species concepts as a whole and not just based on phylogenetic data. Finally we wanted to examine the correlation between different genera and species and different citrus leaf spot symptoms.

\section{MATERIALS AND METHODS}

Isolates.-Symptomatic leaves were collected from major citrus growing areas in China including Fujian, Guangdong, Guizhou, Hunan, Jiangxi, Yunnan, Zhejiang provinces and the Guangxi Zhuang Autonomous Region (Fig. 1). The main sampled Citrus varieties were grapefruit, mandarin, orange, pomelo and tangerine (TABLE I). Collected symptomatic leaves, fruits and other citrus tissues were washed with running water to remove the dust and were dried with absorbent paper. To obtain the fungal strains, the dried tissues were surface-disinfected by scrubbing thoroughly ( 5 times) with a cotton ball dipped in $75 \%$ ethanol. After drying under a laminar flow hood, a small piece $(3 \times 3 \mathrm{~mm})$ of tissue was removed from the junction of infected and healthy tissue and plated on $2 \%$ potato dextrose agar (PDA, according to Crous et al. 2009b) plates amended with $100 \mu \mathrm{g} / \mathrm{mL}$ ampicillin and streptomycin to inhibit bacterial growth and incubated at $25 \mathrm{C}$. Emerging colonies were transferred to fresh PDA plates, and fertile colonies single-spored and stored at 4 C (see Crous et al. 2009b) (TABLE II). Additional strains were obtained from the working collection of Pedro Crous (CPC) housed at CBS, as well as the CBS culture collection (Utrecht, the Netherlands).

DNA extraction, PCR amplification and sequencing.-Isolates were cultured $7 \mathrm{~d}$ on PDA at $25 \mathrm{C}$, the mycelia harvested with a sterile blade and placed in centrifuge tubes. DNA was extracted with the Biospin Fungus Genomic DNA Extraction Kit (Bio-Flux, Bior Technology Co., China) and used for PCR amplification. Six primer pairs were used to amplify partial sequences of nuclear ribosomal RNAs ITS1-5.8S-ITS2 regions (ITS), and partial actin (act), $\beta$-tubulin (tub2), $28 \mathrm{~S}$ ribosomal RNA gene (28S rDNA) and translation elongation factor 1- $\alpha$ (tef1)genes. Sequences of primers followed the studies, ITS4/ITS5 (White et al. 1990), ACT-512F/ACT783-R (Carbone and Kohn 1999), Bt2a (Glass and Donaldson 1995) or T1 (O’Donnell and Cigelnik 1997), /Bt2b (Glass and Donaldson 1995) or $\beta$-Sandy-R (Stukenbrock et al. 2012), LSU1Fd (Crous et al. 2009a), /LR5 (Vilgalys and Hester 1990) and EF1-728F (Carbone and Kohn 1999), /EF2(O'Donnell et al. 1998). The amplified products were sequenced in both directions and a consensus sequence determined (Sunny Biotechnology Co. Ltd, Shanghai, China) for the phylogenetic analyses. All sequences produced in this study were submitted to GenBank (TABLE II).

Phylogenetic analyses.-Resulting sequences were used to identify additional related sequences deposited in the NCBI GenBank nucleotide databases using megablast queries and subjected to multiple sequences alignments with the online interface of MAFFT 6 (Katoh and Toh 2010) and manually corrected where necessary. Two datasets were constructed; the first using the $28 \mathrm{~S}$ rDNA data only to determine the generic relationships among the obtained isolates (FIG. 2) and the second from a combined ITS, tef1, 28S rDNA and tub2 alignment representing species of Zasmidium (FIG. 3). The act phylogeny was not congruent with the other phylogenies in that three isolates of Zasmidium fructicola (ZJUM50, ZJUM77, ZJUM89) and a single isolate of Z. fructigenum (ZJUM99) formed separate lineages intermediate between the $Z$. fructigenum and $Z$. fructicola clades, with Zasmidium xenoparkii (CBS 111185) clustering basal within the $Z$. fructigenum clade. Therefore this locus was excluded from the combined analysis. Congruency of the sequence datasets for the separate loci were determined with tree topologies of $70 \%$ reciprocal neighbor-joining bootstrap trees with maximum 


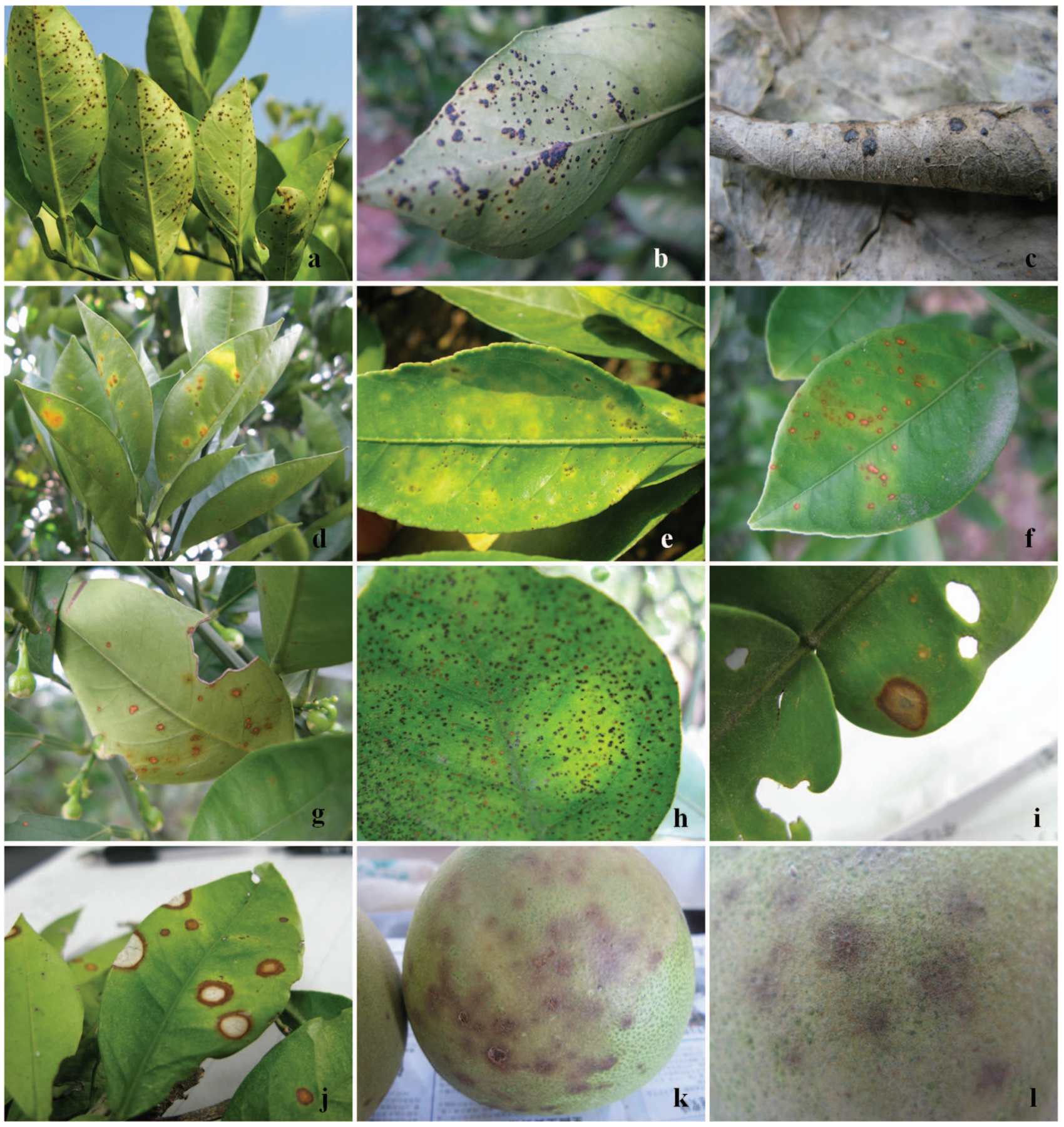

FIG. 1. Symptoms of citrus greasy spot in China. a, b. Greasy spot. c. Greasy spot on decayed leaf of grapefruit; d, e. Yellow spot. f, g. Upper and lower side of brown small round spot on leaves of grapefruit, respectively. h. Black or brown dot on leaf of grapefruit. i, j. Big round spot on leaves of pomelo and grapefruit, respectively. k, l. Similar greasy spot on fruits of pomelo.

likelihood distances that were compared visually to identify conflicts between partitions (Mason-Gamer and Kellogg 1996, Gueidan et al. 2007). A maximum parsimony analysis was performed on the alignments with PAUP (Phylogenetic analysis using parsimony) 4.0b10 (Swofford 2003) using the heuristic search option with 100 random sequence additions and tree bisection and reconstruction (TBR) as the branchswapping algorithm. Branches of zero length were collapsed, and the first 1000 multiple, equally most parsimonious trees were saved. The robustness of the trees obtained was evaluated by 1000 bootstrap replications (Hillis and Bull 1993). All characters were weighted equally, and alignment gaps were treated as new state data. Tree length, consistency indexes $(\mathrm{CI})$, retention indexes (RI), rescaled consistency indexes (RC) and homoplasy indexes (HI) were calculated for the resulting trees. The resulting phylogenetic trees 
TABLE I. The sampling information of Chinese citrus greasy spot-associated material

\begin{tabular}{|c|c|c|c|c|}
\hline Province ( 8 total) & County (17 total) & Host & Tissue & No. of isolates (82 total) \\
\hline \multirow[t]{2}{*}{ Fujian } & Nanjing & Citrus grandis (pomelo, Guanximiyou) & Fruit & 2 \\
\hline & Pinghe & Citrus grandis (pomelo, Guanximiyou) & Fruit & 6 \\
\hline \multirow[t]{2}{*}{ Guangdong } & Dabu & Citrus grandis (pomelo, Guanximiyou) & Fruit & 1 \\
\hline & Pingyuan & Citrus sinensis (orange) & Fruit & 1 \\
\hline \multirow[t]{4}{*}{ Guangxi } & Yangsuo & Citrus sp. & Leaf & 1 \\
\hline & & Citrus sinensis (orange) & Leaf & 1 \\
\hline & & Fortunella margarita (kumquat) & Leaf & 1 \\
\hline & & Citrus grandis (pomelo, Shatianyou) & Fruit & 4 \\
\hline \multirow[t]{2}{*}{ Guizhou } & Congjiang & Citrus reticulata (tangerine, Ponkan) & Leaf & 2 \\
\hline & & & Twig & 2 \\
\hline Hunan & Jishou & Citrus reticulata (tangerine, Ponkan) & Fruit & 3 \\
\hline Jiangxi & Nanfeng & Citrus reticulata (tangerine, Nanfengmiju) & Fruit & 2 \\
\hline \multirow[t]{2}{*}{ Yunnan } & Mengdian & Citrus limon (lemon) & Leaf & 2 \\
\hline & & Citrus aurantifolia (key lime) & Leaf & 1 \\
\hline \multirow[t]{18}{*}{ Zhejiang } & Cangnan & Citrus grandis (pomelo, Sijiyou) & Leaf & 3 \\
\hline & & & Fruit & 2 \\
\hline & Changshan & Citrus paradisi $\times$ C. sp. (grapefruit, Changshanhuyou) & Leaf & 12 \\
\hline & & & Fruit & 8 \\
\hline & Huangyan & Citrus reticulata (tangerine, Ponkan) & Leaf & 1 \\
\hline & & & Fruit & 2 \\
\hline & & Citrus unshiu (mandarin) & Fruit & 2 \\
\hline & Jiangshan & Citrus paradisi $\times$ C. sp. (grapefruit, Changshanhuyou) & Leaf & 1 \\
\hline & Linhai & Citrus unshiu (mandarin) & Fruit & 1 \\
\hline & & Citrus sinensis (orange) & Fruit & 1 \\
\hline & Longyou & Citrus paradisi $\times$ C. sp. (grapefruit, Changshanhuyou) & Leaf & 6 \\
\hline & & Citrus grandis (pomelo) & Leaf & 6 \\
\hline & Quzhou & Citrus paradisi $\times$ C. sp. (grapefruit, Changshanhuyou) & Leaf & 1 \\
\hline & & & Fruit & 2 \\
\hline & & Citrus reticulata (tangerine, Ponkan) & Fruit & 1 \\
\hline & & Citrus unshiu (mandarin) & Leaf & 1 \\
\hline & Yuhuan & Citrus grandis (pomelo, Wendanyou) & Leaf & 1 \\
\hline & & & Fruit & 2 \\
\hline
\end{tabular}

(FIGS. 2, 3) were printed with Geneious 5.5.4 (Drummond et al. 2011) and the layout of the tree for publication was done in Adobe Illustrator CS5.1. Sequences derived in this study were lodged at GenBank, the alignments and trees in TreeBASE (www.treebase.org/treebase/index.html).

Morphology.-Colonies were studied on PDA, oatmeal agar (OA) (Crous et al. 2009c) and pine needle agar (PNA) (Smith et al. 1996), and incubated at $25 \mathrm{C}$ under continuous near-ultraviolet light to promote sporulation. Observations were made under a Zeiss V20 Discovery stereomicroscope and with a Zeiss Axio Imager 2 light microscope using differential interference contrast (DIC) illumination and an AxioCam MRc5 camera and ZEN software. Measurements and photographs were made from structures mounted in clear lactic acid. The $95 \%$ confidence intervals were derived from 30 observations $(1000 \times$ magnification $)$, with the extremes in parentheses. Ranges of the dimensions of other characters are provided. Colony characters and pigment production were noted after 2 wk growth on media incubated at $25 \mathrm{C}$ in the dark. Colony colors (surface and reverse) were rated according to the color charts of Rayner (1970). Morphological descriptions were based on cultures sporulating on PNA. Reference strains were deposited in CBS, descriptions and nomenclatural data in MycoBank (Crous et al. 2004a).

\section{RESULTS}

Isolates.-In total 82 isolates were collected from China, supplemented with 15 isolates from other countries (TABLE II). Of the Chinese isolates, nine were recorded without any specific foliar disease symptoms, while 73 isolates were associated with citrus greasy spot 
Huang et al.: Cercosporoid diseases of Citrus

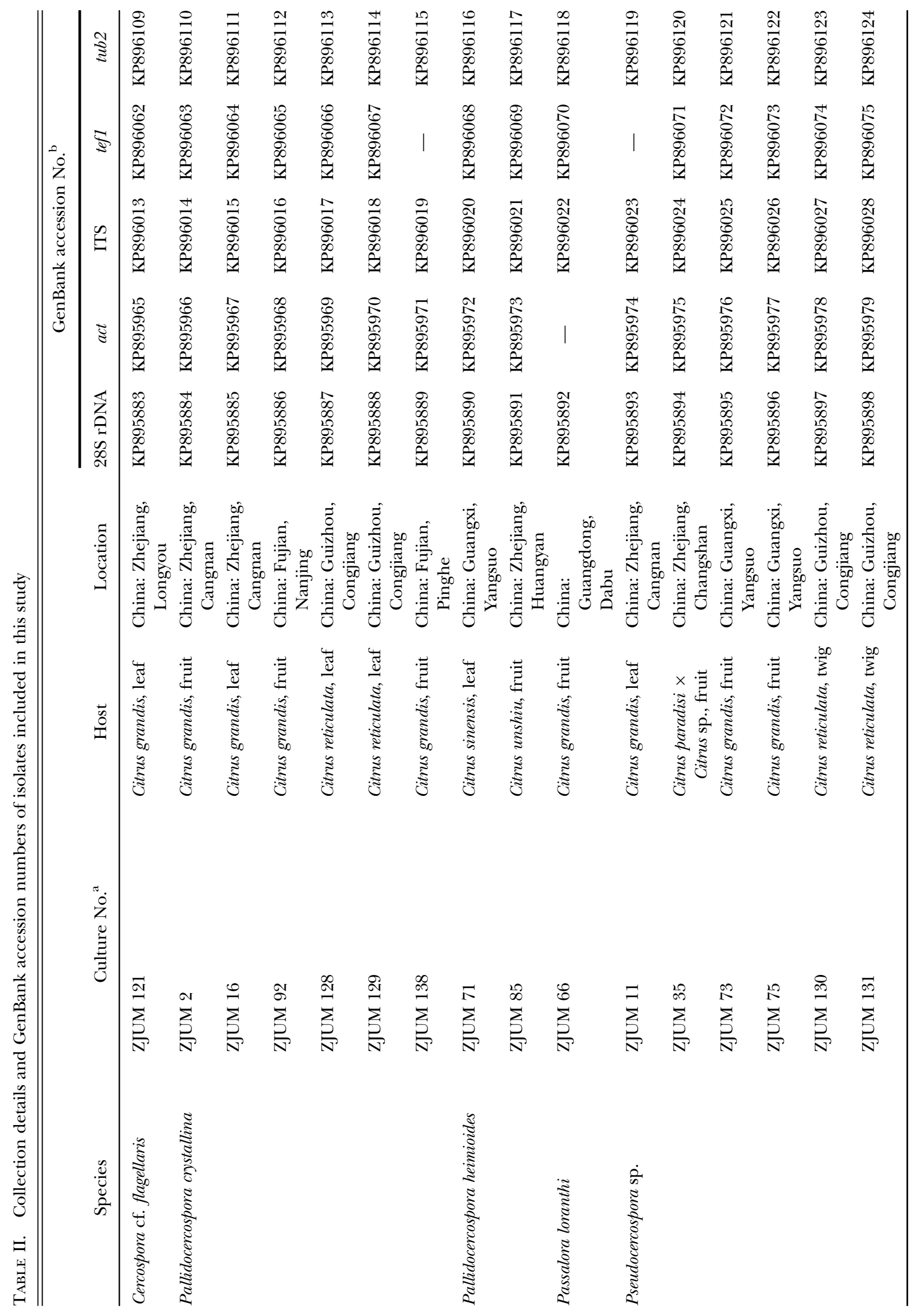


Huang et al.: Cercosporoid diseases of Citrus

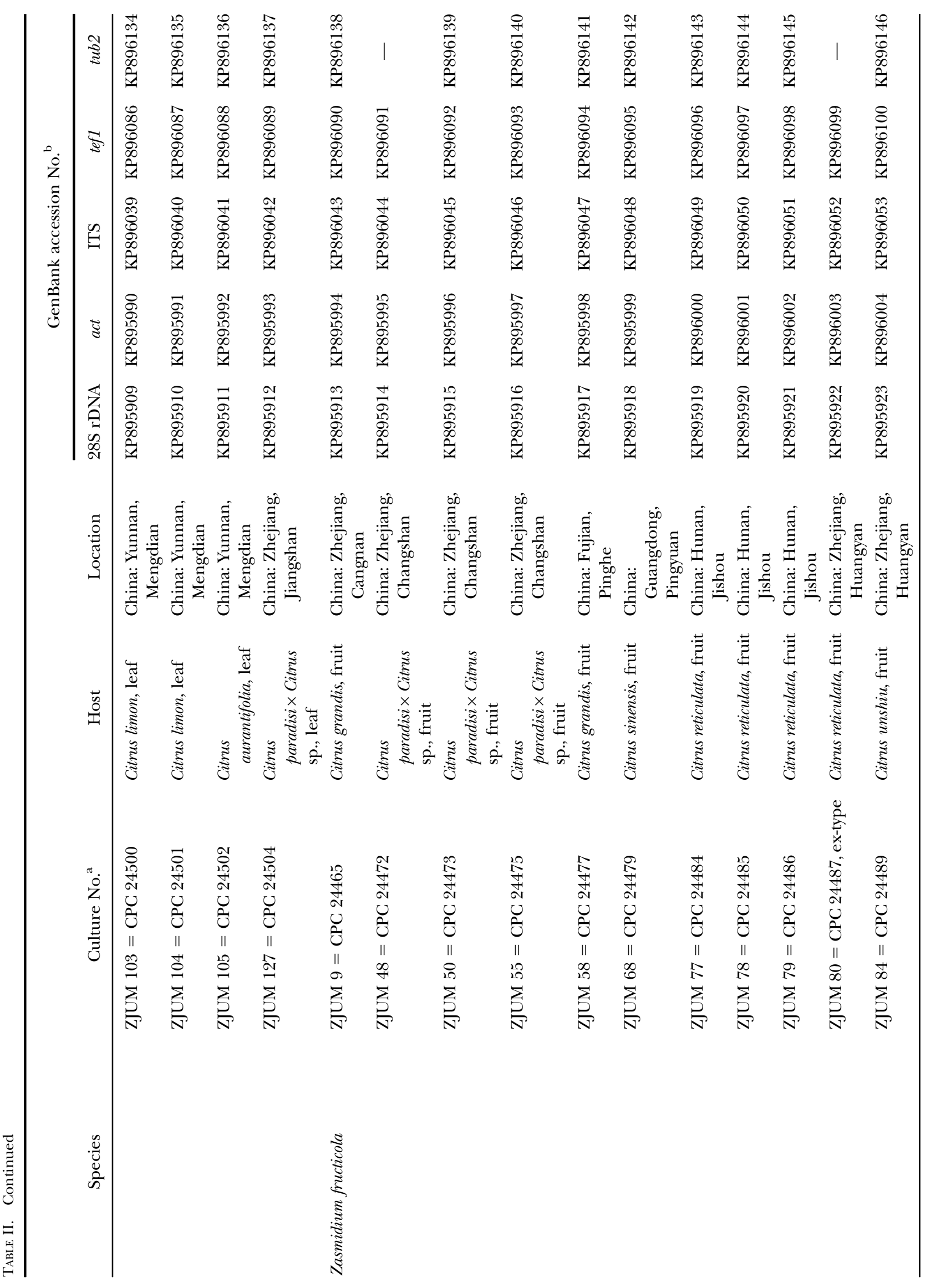


Huang et al.: Cercosporoid diseases of Citrus

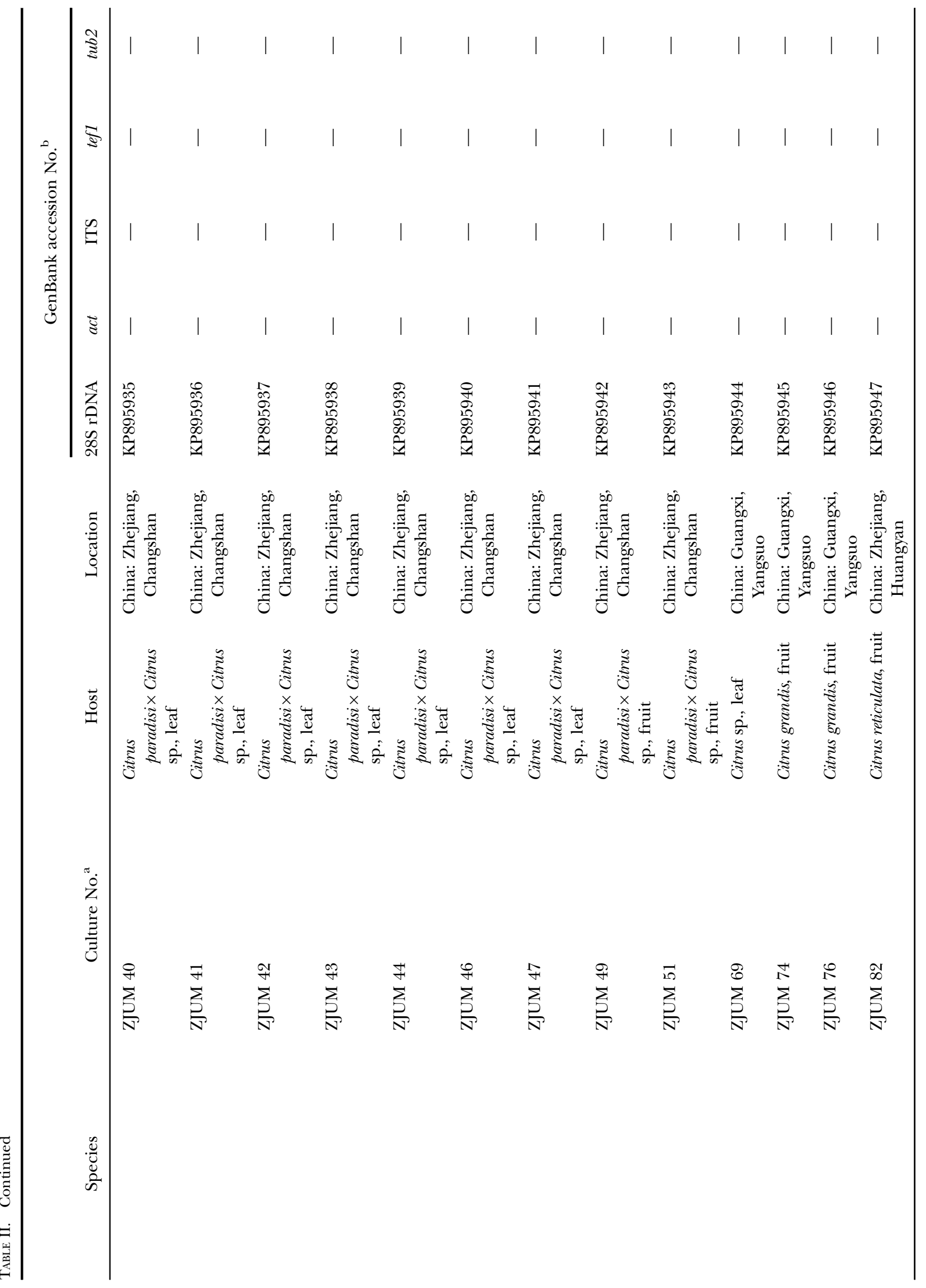




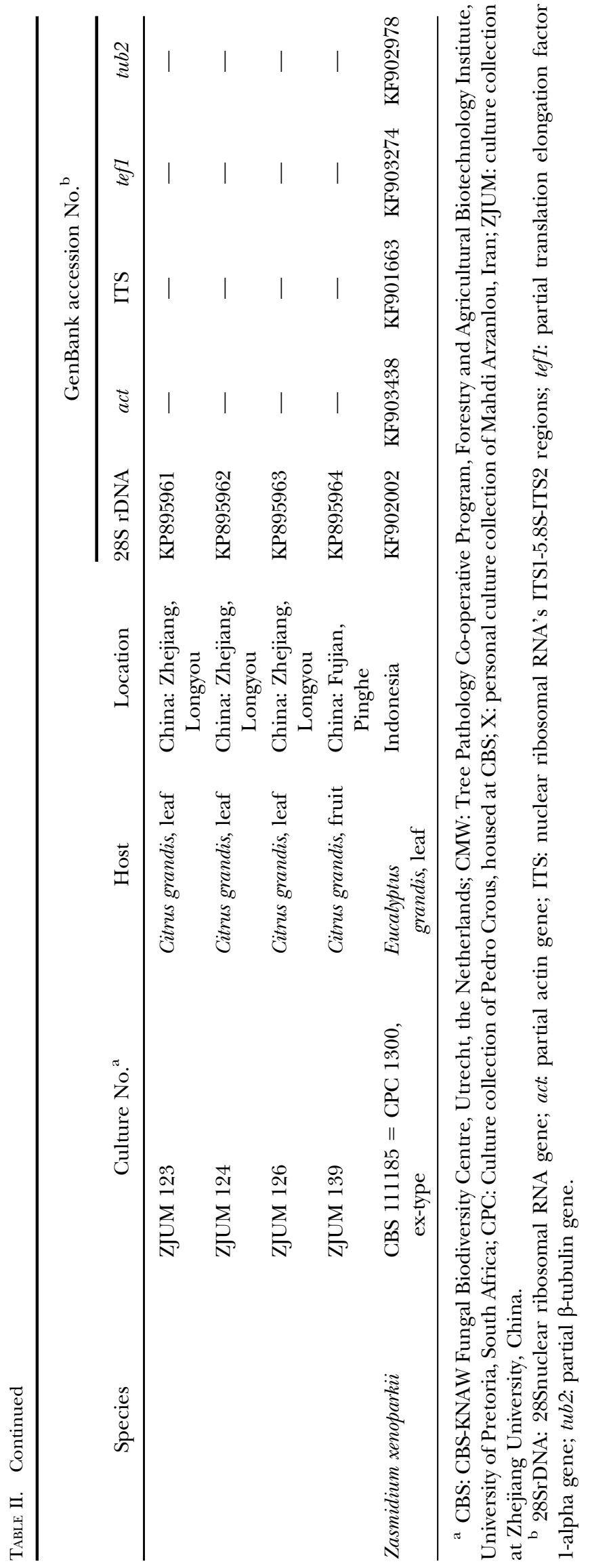

and a range of other symptoms. Of these 17 isolates were collected from greasy spot symptoms (Fig. 1ac), 16 from yellow spot symptoms (FIG. 1d, e), 14 from small, brown spots (Fig. 1f, g), nine from black dot symptoms, resembling melanose (FIG. 1h), six from big round spots (FIG. 1i, j), five from greasy spot slacking black protuberances (FIG. 1k, l), four from citrus black spots (Wang et al. 2012) and one isolate from brown dot (FIg. 1h) and healthy fruit, respectively.

Phylogenetic analyses. - In this study we aimed to classify cercosporoid isolates from Citrus by employing a consolidated species concept incorporating morphological and phylogenetic data. However, many isolates proved to be sterile. An analysis of the 28S rDNA sequences was performed to determine the generic relationships of the obtained isolates; this analysis was based on 108 isolates, including the outgroup sequence, and the resulting dataset of 754 characters, including alignment gaps which are treated as fifth base, consisted of 595 constant characters, 44 variable parsimony-uninformative characters and 115 parsimony-informative characters. Twenty equally most parsimonious trees were retained, the first of which is presented (FIG. 2). Based on the 28Sr DNA phylogeny (FIG. 2), isolates from China clustered in clades corresponding to the genera Cercospora (one isolate), Pallidocercospora (eight isolates), Passalora (one isolate), Pseudocercospora (three isolates, with a further six isolates not included in the phylogeny), Verrucisporota (one isolate) and Zasmidium (23 isolates, with a further 39 isolates not included in the phylogeny). Most of the isolates were found to be members of the genus Zasmidium, and these could be induced to sporulate on PNA.

The Zasmidium isolates were selected for a multigene (ITS, tef1, 28S rDNA, tub2) phylogenetic analysis (FIG. 3), which could resolve six species, four of which occurred on Citrus. This analysis was based on 46 isolates, including the two outgroup sequences, and the resulting dataset of 1822 characters $(488,328,747$ and 259 characters for ITS, tef1, 28S rDNA and $t u b 2$, respectively), including alignment gaps which were treated as fifth base, consisted of 1276 constant characters, 185 variable parsimony-uninformative characters and 361 parsimony-informative characters. The maximum of 1000 equally most parsimonious trees were retained, the first of which is presented (FIG. 3).

\section{TAXONOMY}

In the present study isolates were found to cluster in clades corresponding to the genera Cercospora, Pallidocercospora, Passalora, Pseudocercospora, Verrucisporota and Zasmidium. Of these, however, only those in the genus 


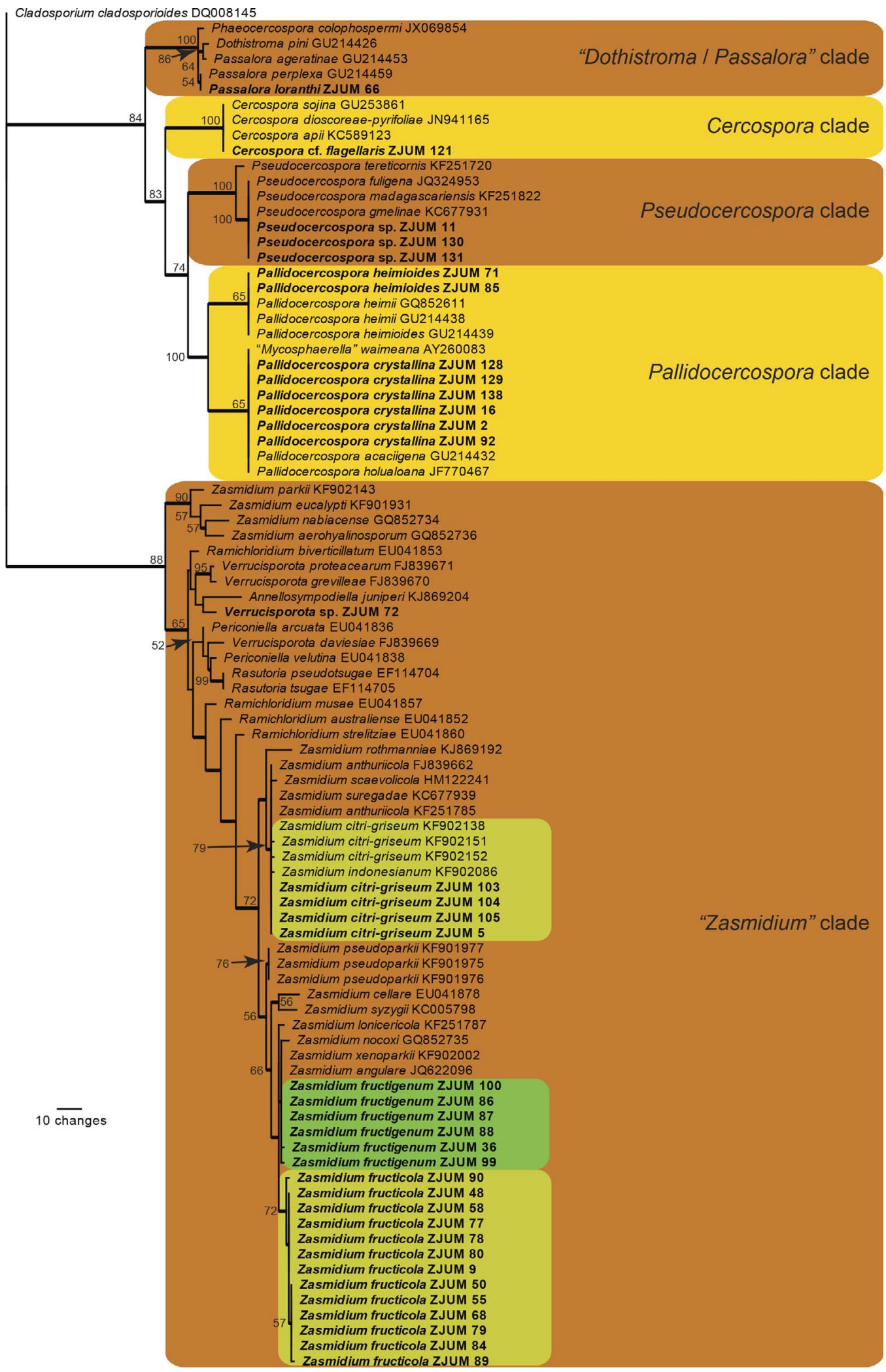

FIG. 2. The first of 20 equally most parsimonious trees $(\mathrm{TL}=372, \mathrm{CI}=0.543, \mathrm{RI}=0.920, \mathrm{RC}=0.500)$ from a parsimony analysis of the 28s rDNA alignment representing cercosporoid genera in the Mycosphaerellaceae. Bootstrap support values are indicated at the nodes, and the bar represents the number of changes. Thickened branches reflect those branches present in the strict consensus tree. Major lineages are indicated with colored blocks and the Zasmidium species of interest in the present study with internal blocks. Isolates from China are in boldface text. The tree was rooted to Cladosporium cladosporioides (GenBank DQ008145). 


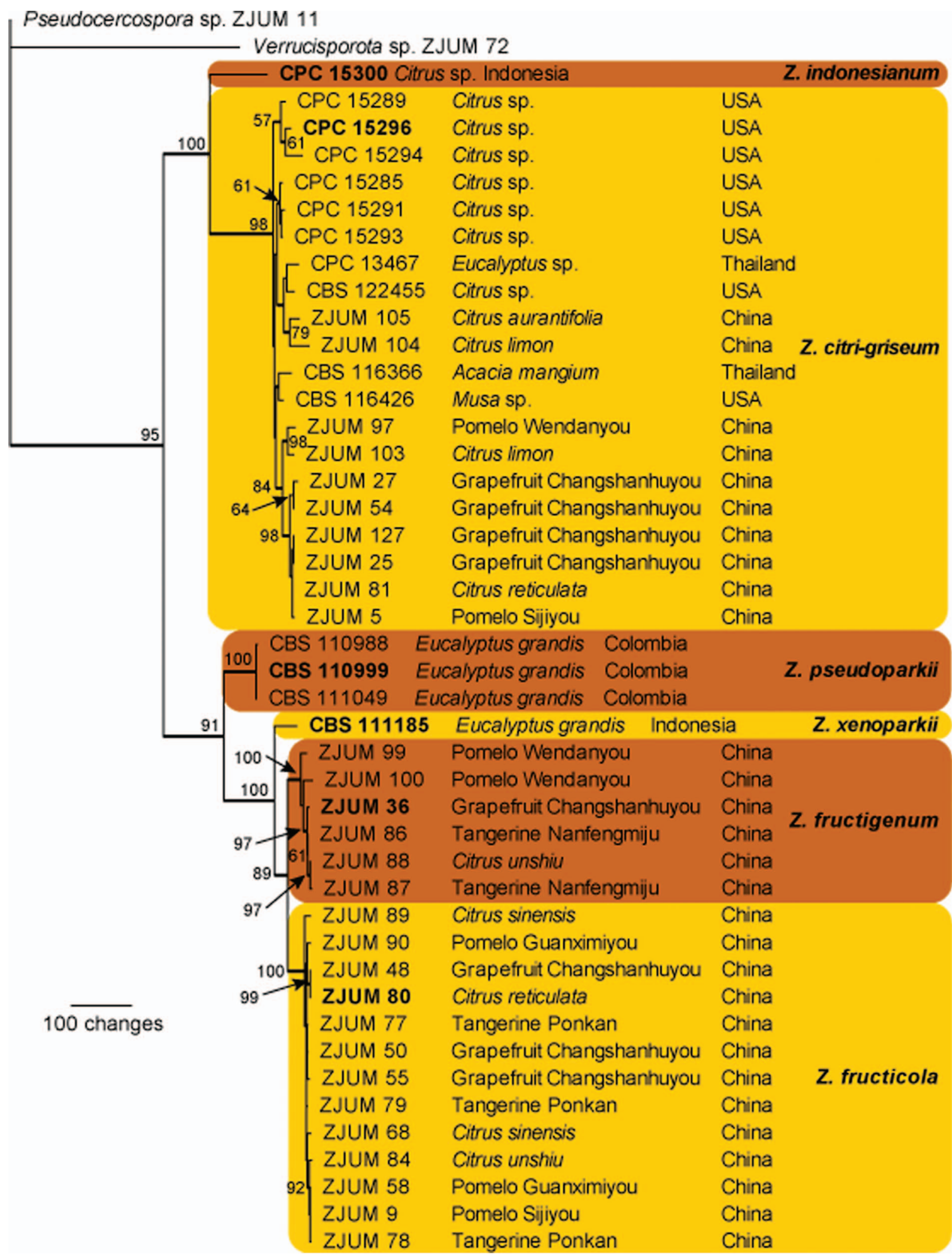

FIG. 3. The first of 1000 equally most parsimonious trees $(\mathrm{TL}=1250, \mathrm{CI}=0.675, \mathrm{RI}=0.907, \mathrm{RC}=0.612)$ from a parsimony analysis of the combined ITS, tef1, 28S rDNA and tub2 alignment representing species of Zasmidium. Bootstrap support values are indicated at the nodes, and the bar represents the number of changes. Thickened branches reflect those present in the strict consensus tree. Species are indicated with colored blocks, and ex-type cultures are in boldface text. The substrate and country of origin are next to culture collection number. The tree was rooted to Pseudocercospora sp. ZJUM 11 and Verrucisporota sp. ZJUM 72 (GenBank accession numbers listed in TABLE II). 

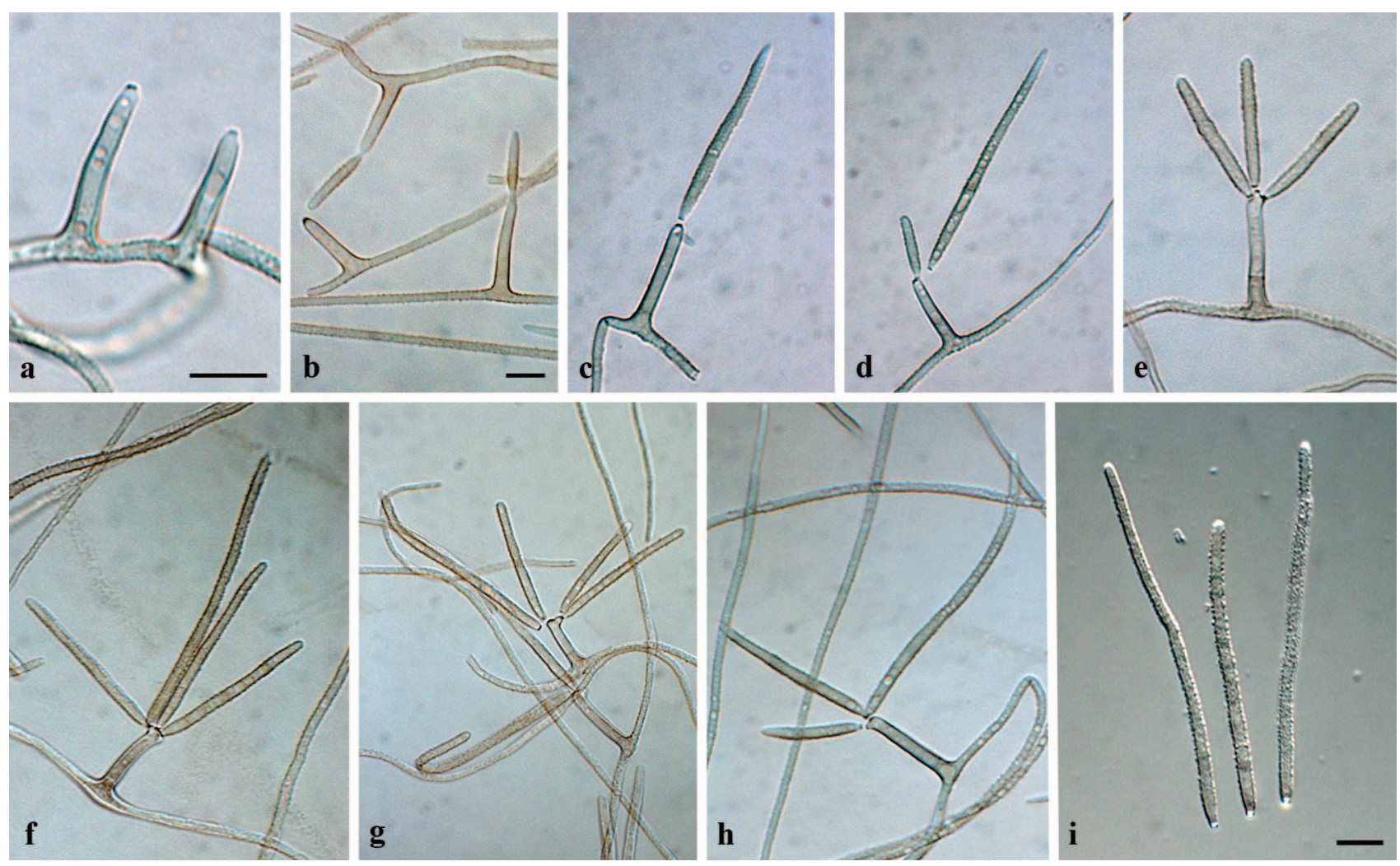

FIG. 4. Zasmidium citri-griseum (CPC 15296). a-i. Solitary conidiophores giving rise to chains of conidia on SNA. Bars $=10 \mu \mathrm{m}$ (b applies to $\mathrm{c}-\mathrm{h}$ ).

Zasmidium could be induced to sporulate. These taxa are treated below.

Zasmidium citri-griseum (F.E. Fisher) U. Braun \& Crous, IMA Fungus 5:337. 2014. Fig. 4.

Basionym. Cercospora grisea F.E. Fisher, Phytopathology 51:300. 1961.

$\equiv$ Stenella citri-grisea (F.E. Fisher) Sivan., Bitunicate Ascomycetes and their Anamorphs: 226. 1984.

$=$ Mycosphaerella citri Whiteside, Phytopathology 62:263. 1972.

$\equiv$ Zasmidium citri (Whiteside) Crous, Persoonia 23:105. 2009.

Typification: USA, FLORIDA: Lake Alfred \& Haines City, on Citrus sp., May 1970, F.E. Fisher (NEOTYPEK [M] IMI 148810); single ascospore isolates, associated with citrus greasy leaf spot disease symptoms, Citrus sp., 2003, S.N. Mondal (EPITYPE designated here CBS H22176, MBT201426, culture ex-epitype CBS $139467=$ CPC 15296).

Description: See Braun et al. (2014).

Additional materials examined: CHINA, YUNNAN PROVINCE: Mengdian, on leaves with yellow spot of Citrus limon (Lemon), Jul 2011, L. Zhu (culturesZJUM $103=$ CPC 24500, ZJUM $104=$ CPC 24501); on leaf with yellow spot of C. aurantifolia (Key lime), Jul 2011,
L. Zhu (culture ZJUM 105 = CPC 24502); ZHEJIANG PROVINCE: Cangnan, on leaf with yellow spot of C. grandis (Pomelo Sijiyou), Dec 2009, L. Zhu (culture ZJUM 5 = CPC 24464); Changshan, on leaves of C. paradisi $\times$ Citrus sp. (Grapefruit Changshanhuyou), May 2009, L. Zhu (culture ZJUM $25=$ CPC 24468, ZJUM 27 = CPC 24469); Nov 2011, L. Zhu (culture ZJUM 54 = CPC 24474); Huangyan, on leaf with big round spot of C. reticulata (Tangerine), Apr 2010, L. Zhu (culture ZJUM 81 = CPC 24488); Yuhuan, on leaf with greasy spot of $C$. grandis (Pomelo Wendanyou), Nov 2011, L. Zhu (culture ZJUM $97=$ CPC 24497); Jiangshan, on leaf with brown small round spot of C.paradisi $\times$ Citrus sp. (Grapefruit Changshanhuyou), Apr 2013, F. Huang (culture ZJUM $127=$ CPC 24504). - THAILAND, on living leaves of Eucalyptus sp., Jan 2006, W. Himaman (culture CPC 13467); Chonburi, on living leaves of seedlings of Acacia mangium, 19 Nov 2002, M.J. Wingfield (culture CPC $10522=$ CBS 116366). - USA, FLORIDA: Polk County, Babson Park, on Citrus limon, 15 Jan 1958, F.E. Fisher (presumably lost); single ascospore isolates, associated with citrus greasy leaf spot disease symptoms, Citrus sp. 2003, S.N. Mondal (cultures CPC 15289, CPC $15290=$ CBS 122455, CPC 15294, CPC 15285, CPC 15291, 
CPC 15293); on leaves of Musa sp., 2003, J. Cavaletto (culture CBS 116426).

Host range and distribution: See Braun et al. (2014).

Notes: When Whiteside (1972) introduced the name Mycosphaerella citri he questioned the conspecificity with Cercospora citri-grisea (Fisher 1961). Fisher (1961) reported conidia to be 0 -multiseptate, $25-200 \times 1.5-$ $3 \mu \mathrm{m}$, whereas Whiteside reported conidia as being 0-9-septate, $6-50 \times 2-3.5 \mu \mathrm{m}$. In their examination of the neotype, Braun et al. (2014) reported conidia to be $(0-) 1-6(-10)$-septate, $6-70(-120) \times 2-4.5 \mu \mathrm{m}$, also questioning the synonymy between the Fisher and Whiteside taxa but choosing the older name, Z. citri-griseum.

Based on an examination of several specimens, Pretorius et al. (2003) regarded this as a single species with wider host range, while Crous et al. (2004) provided molecular data to show that this taxon also could occur on Acacia mangium (Thailand) and Musa sp. (USA). Furthermore, Arzanlou et al. (2008) added an isolate from Musa sp. (Tonga) while Maxwell et al. (2005) reported this species on Eucalyptus camaldulensis (Vietnam) and Crous et al. (2009b) on Eucalyptus sp. (Thailand).

In the present study we added several single-ascospore isolates from Florida in USA (Mondal et al. 2004) to the molecular analyses, which reveals conidia of this species to be morphologically variable, with those of the neotype being solitary or catenulate, 0 multiseptate, (6-) 45-70(-120) × 2-4.5 $\mu \mathrm{m}$. Isolate CPC 24500 from citrus in China had conidia that occurred in branched chains, 0-multiseptate, 20-200 $\times 2.5-3 \mu \mathrm{m}$. Isolate CBS 116366 from Acacia in Thailand had conidia that were 0 -multiseptate, occurring mostly in unbranched chains, (15-)45-65(-120) $\times$ (2-)2.5-3 $\mu \mathrm{m}$. Although there appears to be some morphological variation in $Z$. citri-griseum, the observed sexual nature of this taxon could account for this and we presently choose to retain it as a single taxon with a cosmopolitan distribution and wide host range until such time as more robust data is presented to prove otherwise. Furthermore, in this study we also found Z. citri-griseum to be associated with a range of disease symptoms, including greasy spot, yellow spot and small brown spot.

Zasmidium fructicola Crous, F. Huang \&Hong Y. Li, sp. nov. Fig. 5

MycoBank MB811381

Typification: CHINA, ZHEJIANG PROVINCE: Huangyan, on fruit of Citrus reticulata (Tangerine), Jan 2010, X.H. Wang (HOLOTYPE CBS H-22177, culture extype ZJUM $80=$ CPC $24487=$ CBS 139625).

Etymology: Named after its occurrence on Citrus fruit.

Description: Colonies sporulating on PNA. Mycelium consisting of pale brown to brown, verruculose, branched, septate, 1.5-2 $\mu \mathrm{m}$ diam hyphae. Conidiophores solitary, erect, subcylindrical, medium brown, straight to once geniculate, $0-2$-septate, $15-25 \times 2.5-$ $3 \mu \mathrm{m}$. Conidiogenous cells integrated, terminal, medium brown, verruculose, subcylindrical, straight to once geniculate, $8-12 \times 2.5-3 \mu \mathrm{m}$; loci sympodial, forming a short rachis with darkened, thickened, refractive, $0.5 \mu \mathrm{m}$ diam scars. Conidia in branched chains, brown, verruculose, subcylindrical to fusoid-ellipsoid, guttulate; ramoconidia 0-1-septate, $10-15 \times 3-4 \mu \mathrm{m}$; conidia aseptate, brown, verruculose, fusoid-ellipsoid, apex subobtuse, base obconically truncate, darkened, refractive, thickened, $0.5 \mu \mathrm{m}$ diam, (5-)7-9(-12) $\times$ (2-) $3 \mu \mathrm{m}$.

Culture characteristics: Colonies flat, spreading with sparse to moderate aerial mycelium and smooth, lobate margins, reaching $40 \mathrm{~mm}$ diam after $2 \mathrm{wk}$ on OA and PDA; on OA surface iron gray (due to collapsed aerial mycelium); on PDA surface and reverse iron gray.

Additional materials examined: CHINA, ZHEJIANG PROVINCE: Huangyan, on fruit with citrus black spot of C. unshiu (Mandarin), Jan 2010, X.H. Wang (culture ZJUM 84 = CPC 24489); Cangnan, on fruit with greasy spot of C. grandis (Pomelo Sijiyou), Oct 2010, L. Zhu (culture ZJUM 9 = CPC 24465); Changshan, on fruit with yellow spot of $C$. paradisi $\times$ Citrus sp. (Grapefruit Changshanhuyou), Nov 2010, L. Zhu (cultures ZJUM 48 = CPC 24472, ZJUM 50 = CPC 24473); on fruit with black dot of C. paradisi $\times$ Citrus sp. (Grapefruit Changshanhuyou), Dec 2010, L. Zhu (culture ZJUM 55 = CPC 24475); Linhai, on fruit with black dot of C. sinensis (Orange), Nov 2010, G.Q. Chen (culture ZJUM 89 = CPC 24494); FUJIAN PROVINCE: on fruit with greasy spot of C. grandis (Pomelo Guanximiyou), Nov 2010, L. Zhu (culture ZJUM 58 = CPC 24477); Nanjing, on fruit with greasy spot of $C$. grandis (Pomelo Guanximiyou), Nov 2009, L. Zhu (culture ZJUM $90=$ CPC 24495); GUANGDONG PROVINCE: Pingyuan, on fruit with citrus black spot of $C$. sinensis (Orange), Nov 2009, X.H. Wang (culture ZJUM $68=$ CPC 24479); HUNAN PROVINCE: Jishou, on fruits of C. reticulata (Tangerine Ponkan), Nov 2011, X.H. Wang (cultures ZJUM $77=$ CPC 24484, ZJUM $78=$ CPC 24485, ZJUM 79 = CPC 24486).

Zasmidium fructigenum Crous, F. Huang \& Hong Y.

Li, sp. nov. FIG. 6

MycoBank MB811382

Typification: CHINA, ZHEJIANG PROVINCE: Changshan, on fruit with greasy spot of Citrus paradise $\times$ Citrus sp. (Grapefruit Changshanhuyou), Nov 2009, L. Zhu (HOLOTYPE CBS H-22178, culture ex-type ZJUM 36 $=$ CPC $24471=$ CBS 139 626).

Etymology: Named after its occurrence on Citrus fruit. 

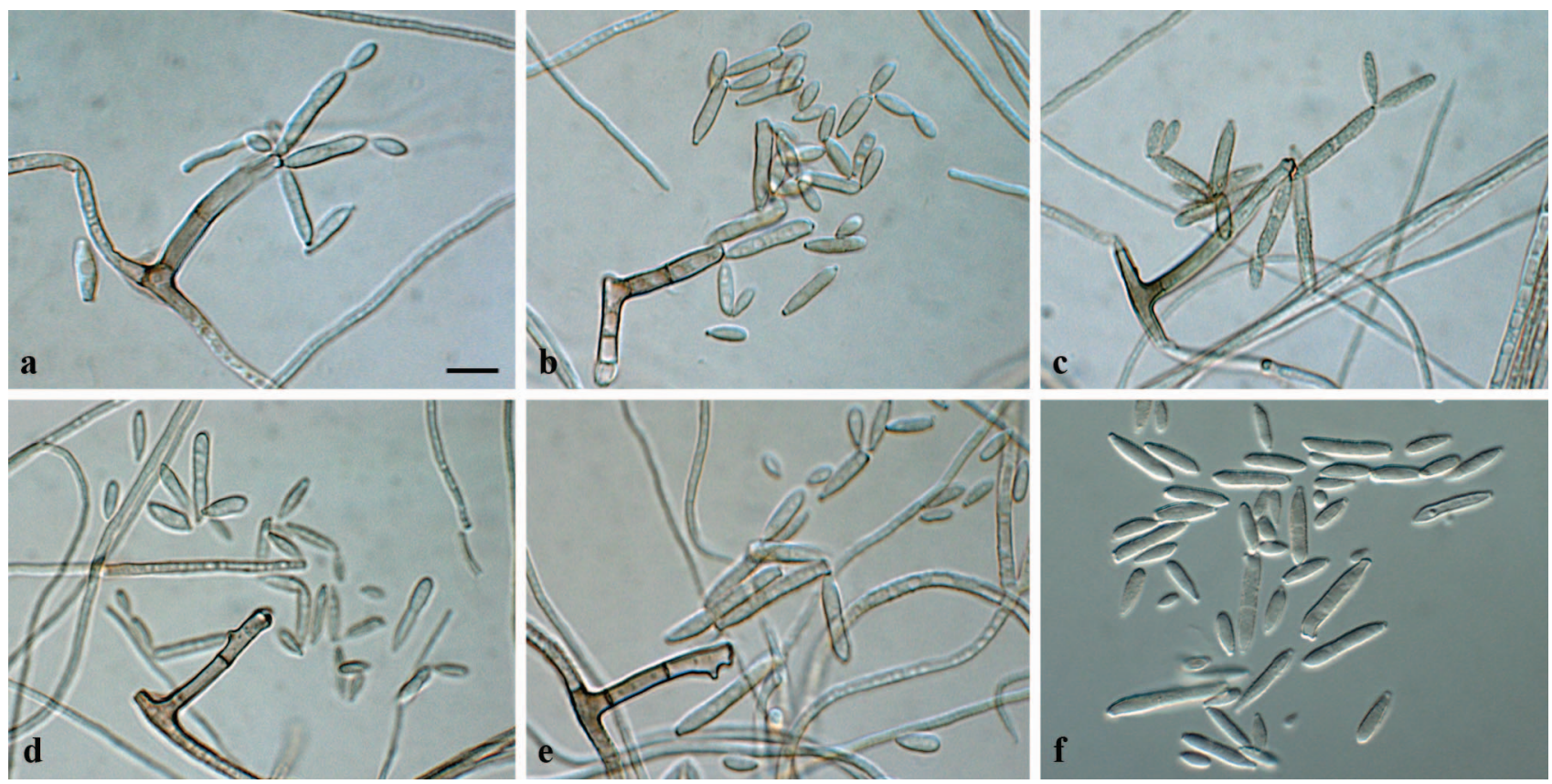

FIG. 5. Zasmidium fructicola (CPC 24487). a-f. Solitary conidiophores giving rise to chains of conidia on SNA. Bars $=10 \mu \mathrm{m}(\mathrm{a}$ applies to all photos).

Description: Colonies sporulating on PNA. Mycelium consisting of pale brown, verruculose, branched, septate, 1.5-2 $\mu \mathrm{m}$ diam hyphae. Conidiophores erect, subcylindrical, medium brown, straight, 1-2-septate, 15$25 \times 2.5-3 \mu \mathrm{m}$. Conidiogenous cells integrated, terminal, medium brown, verruculose, subcylindrical, 15$20 \times 2.5-3 \mu \mathrm{m}$; loci sympodial, forming a short rachis with darkened, thickened, refractive, $0.5 \mu \mathrm{m}$ diam scars. Conidia in branched chains, pale brown, verruculose, subcylindrical, guttulate; ramoconidia 0-1-septate, 10-22 × $2 \mu \mathrm{m}$; conidia 0-1-septate, subcylindrical to narrowly obclavate, apex subobtuse, base obconically truncate, darkened, refractive, thickened, $0.5 \mu \mathrm{m}$ diam, (5-)8-12(-15) $\times 2 \mu \mathrm{m}$.

Culture characteristics: Colonies flat, spreading with moderate aerial mycelium and smooth, lobate margins, reaching $40 \mathrm{~mm}$ diam after $2 \mathrm{wk}$ on OA and PDA; on OA surface smoke gray in center, olivaceous gray in outer region; on PDA surface and reverse iron gray.

Additional materials examined: CHINA, ZHEJIANG PROVINCE: Yuhuan, on fruits with greasy spot of C. grandis (Pomelo Wendanyou), Nov 2010, L. Zhu (cultures ZJUM $99=$ CPC 24498, ZJUM $100=\mathrm{CPC}$ 24499); Linhai, on fruit with black dot of C. unshiu (Mandarin), Nov 2010, G.Q. Chen (culture ZJUM 88 = CPC 24493); JIANGXI PROVINCE: on fruit with citrus black spot of $C$. reticulata (Tangerine Nanfengmiju), Nov 2010, X.H. Wang (cultures ZJUM $86=$ CPC 24491, ZJUM 87 = CPC 24492).
Note: Zasmidium fructicola differs from Z. fructigenum by having conidiophores that are more irregular in appearance (geniculate) and conidia that are brown rather than pale brown, wider and more fusoidellipsoid.

Zasmidium indonesianum Crous, F. Huang \& Hong Y. Li, sp. nov. Fig. 7

MycoBank MB811383

Typification: INDONESIA: on leaf spots of Citrus sp., 2004, M. Arzanlou (HOLOTYPE CBS H-22179, culture ex-type CPC $15300=$ CBS 139627); additional collections from same host and locality (CPC 15301, CPC 15302).

Etymology: Named after the country from where it was collected, Indonesia.

Description: Colonies sporulating on PNA. Mycelium consisting of pale brown, verruculose, branched, septate, 1.5-2 $\mu \mathrm{m}$ diam hyphae. Conidiophores erect, subcylindrical, medium brown, straight, 0-2-septate, $15-25 \times 2.5-3 \mu \mathrm{m}$. Conidiogenous cells integrated, terminal, medium brown, verruculose, subcylindrical, 12-15 × 2.5-3 $\mu \mathrm{m}$; loci sympodial, 1-3 at apex, with darkened, thickened, refractive, $0.5-1 \mu \mathrm{m}$ diam scars. Conidia mostly solitary, pale brown, verruculose, guttulate, (0-)3-6(-multiseptate), subcylindrical to narrowly obclavate, apex subobtuse, base obconically truncate, darkened, refractive, thickened, $0.5 \mu \mathrm{m}$ diam, $(10-) 25-45(-70) \times(2-) 2.5-$ $3 \mu \mathrm{m}$. 

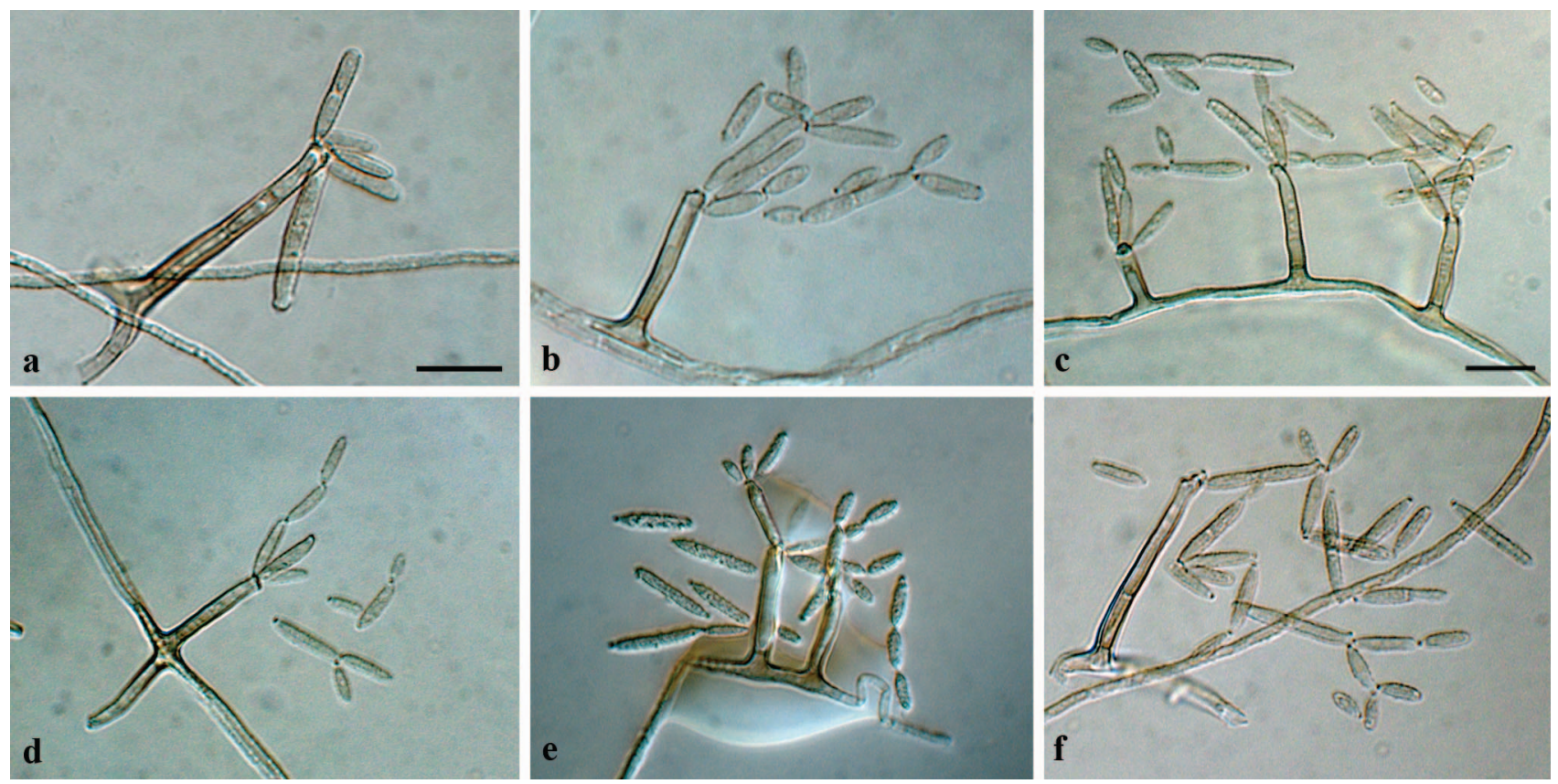

FIG. 6. Zasmidium fructigenum (CPC 24471). a-f. Solitary conidiophores giving rise to chains of conidia on SNA. Bars $=10 \mu \mathrm{m}$ (a applies to b, c applies to $\mathrm{d}-\mathrm{f}$ ).

Culture characteristics: Colonies flat, spreading with moderate aerial mycelium and smooth, lobate margins, reaching $30 \mathrm{~mm}$ diam after 2 wk on MEA; on MEA surface olivaceous gray, reverse iron gray.

Notes: Zasmidium indonesianum differs from Z. fructicola and Z. fructigenum based on its larger conidia, being up to $70 \mu \mathrm{m}$ long, mostly formed singly. Zasmidium citri-griseum differs from all three species by having wider scars and conidial hila and long, curved, multiseptate conidia, up to $120 \mu \mathrm{m}$ long or sometimes even longer.

\section{A KeY TO ZASMIDIUM SPECIES ON CITRUS}

1. Conidia short, generally shorter than $25 \mu \mathrm{m} \ldots \ldots .2$

$1^{\prime}$. Conidia long, generally longer than $25 \mu \mathrm{m} \ldots \ldots . .3$

2 . Conidia in branched chains, pale brown, subcylindrical, $10-22 \times 2 \mu \mathrm{m} . \ldots \ldots$. . . fructigenum

$2^{\prime}$. Conidia in branched chains, brown, subcylindrical to fusoid-ellipsoid, $10-15 \times 3-4 \mu \mathrm{m}$. . . Z. fructicola

3. Conidia mostly solitary, pale brown, (0-)3-6(-multi) septate, $(10-) 25-45(-70) \times(2-) 2.5-3 \mu \mathrm{m}$, up to $70 \mu \mathrm{m}$ long. . . . . . . . . . . . Z. indonesianum

$3^{\prime}$. Conidia solitary or catenate, long, curved, multiseptate, up to $120 \mu \mathrm{m}$ long or sometimes even longer. . . . . . . . . . . . . citri-griseum

\section{Discussion}

Because the recognition that Mycosphaerella represents a polyphyletic assemblage of taxa (Crous et al. 2007), the taxonomy of fungi formerly accommodated under this name underwent significant changes and presently is thought to represent more than 40 different genera in the Capnodiales (Crous 2009, Crous et al. 2009a, Quaedvlieg et al. 2014). Although these genera are chiefly delineated based on their DNA sequence data, in most cases they also correlate with the distinct morphology of their asexual morphs (Crous et al. 2009b). Much of the research on this complex in recent years has been based on revising the mycosphaerella-like fungi associated with specific plant hosts like Acacia (Crous et al. 2004c), Eucalyptus (Crous et al. 2004b, Cheewangkoon et al. 2008), Citrus (Crous and Braun 2003, Pretorius et al. 2003), Musa (Arzanlou et al. 2008), Proteaceae (Crous et al. 2008) and Myrtaceae (Hunter et al. 2006, Perez et al. 2013). In the present study we aimed to determine which cercosporoid species occur on Citrus, focusing primarily on those isolated from various Citrus plantations in China.

Based on the phylogenetic analyses of the $28 \mathrm{~S}$ rDNA sequence data, all strains from this study could be placed in Cercospora, Pallidocercospora, Passalora, Pseudocercospora, Verrucisporota and Zasmidium. In addition, four species of Zasmidium could be distinguished on Citrus, namely Z. citri-griseum, Z. fructicola, Z. fructigenum and Z. indonesianum.

Of these species Z. citri-griseum (= Mycosphaerella citri) is recognized as the causal agent of citrus greasy spot and has greatly affected the citrus industry worldwide (Fisher 1961, Braun et al. 2014). Based on our results, however, this pathogen is not only restricted 

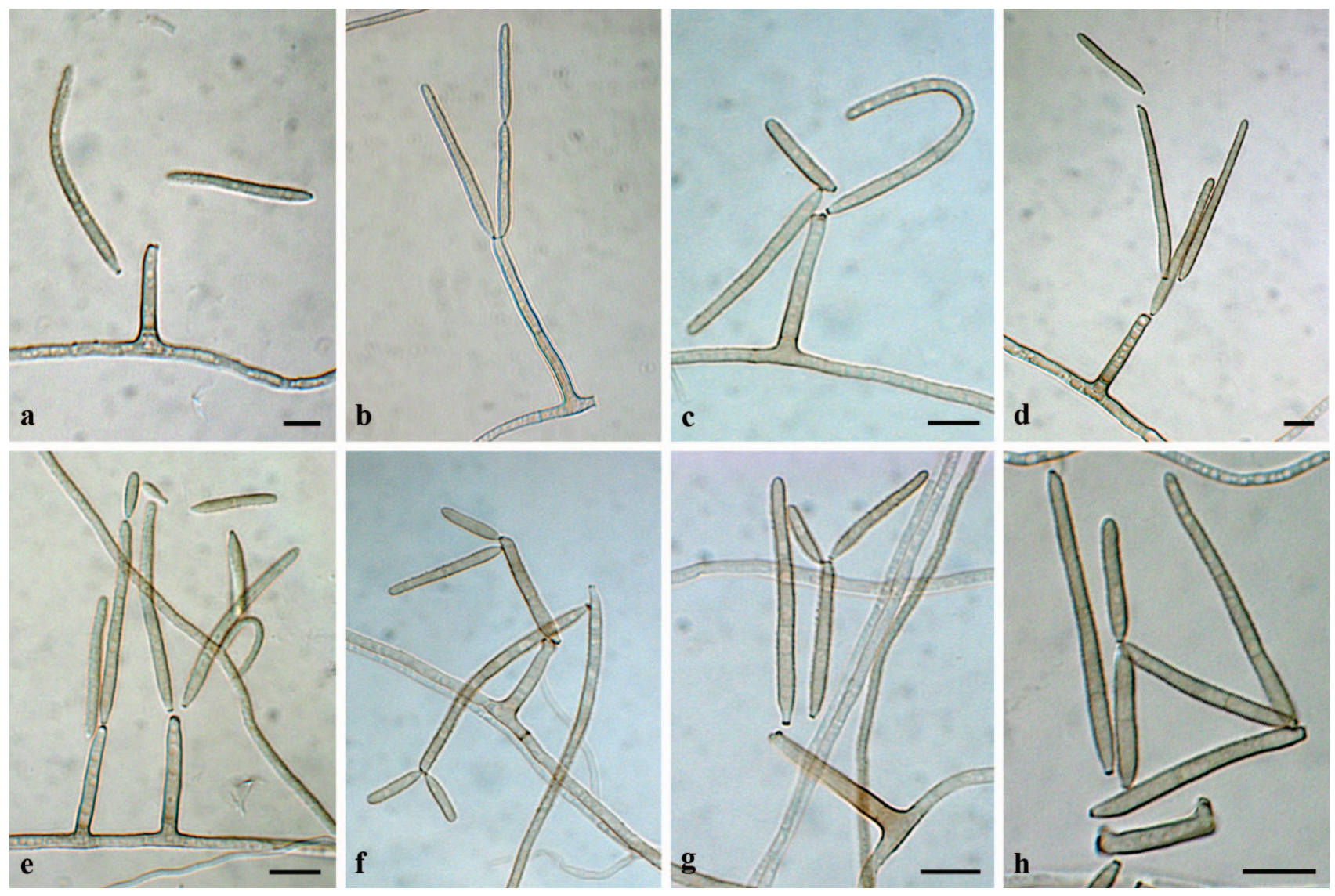

FIG. 7. Zasmidium indonesianum (CPC 15300). a-f. Solitary conidiophores giving rise to chains of conidia on SNA. Bars $=10 \mu \mathrm{m}$ (a applies to b, e applies to f).

to Citrus but also occurs on other plant hosts such as Eucalyptus sp., Acacia mangium and Musa sp. (Crous et al. 2004c, Maxwell et al. 2005, Arzanlou et al. 2008, Crous et al. 2009b).

Other than Z. citri-griseum, Z. fructicola was represented by 13 isolates, which were isolated from citrus fruits exhibiting greasy spot and yellow spot symptoms but not small brown spot symptoms. Zasmidium fructigenum was represented by six isolates that also were obtained from citrus fruits exhibiting greasy spot symptoms but not yellow spot or small brown spot. Zasmidium indonesianum occurred on leaf spots of Citrus sp. and thus far is known only from this host in Indonesia.

The complexity of the disease symptomatology associated with multiple fungal species made it difficult to clearly link species to symptom types. Disease symptoms on a specific host might often be associated with and caused by several cercosporoid pathogens (Crous et al. 2004b, 2013; Groenewald et al. 2013). Furthermore, the symptoms of a specific disease, caused by the same agent, could vary depending on development period of disease, species or cultivars of the host, maturational stage of the infected tissue, as well as the environment (Timmer and Gottwald 2000, Timmer et al. 2000).

In total 15 isolates were obtained from greasy spot symptoms, including two isolates of Z. citri-griseum, three of $Z$. fructicola, three of $Z$. fructigenum, three of Pseudocercospora sp. and four of Pallidocercospora crystallina, suggesting that this kind of symptom on Citrus is associated with multiple cercosporoid fungi. However, four of the 10 isolates obtained from yellow spot symptoms were Z. citri-griseum, as were one of the two isolates obtained from small brown spot symptoms. These results therefore suggest that the latter two disease symptoms are prone to be caused by infections of $Z$. citri-griseum and that this species is not solely associated with greasy spot disease symptoms.

\section{ACKNOWLEDGMENTS}

This work was supported by China Agriculture Research System (CARS-27) and the special funding for Agro-scientific 
Research in the Public Interest (201203034, 201303023). We thank the technical staff, Arien van Iperen (cultures), Marjan Vermaas (photographic plates) and Mieke Starink-Willemse (DNA isolation, amplification and sequencing) for their invaluable assistance.

\section{LITERATURE CITED}

Arzanlou M, Groenewald JZ, Fullerton RA, Abeln ECA, Carlier J, Zapater MF, Buddenhagen IW, Viljoen A, Crous PW. 2008. Multiple gene genealogies and phenotypic characters differentiate several novel species of Mycosphaerella and related anamorphs on banana. Persoonia 20:19-37, doi:10.3767/003158508X302212

Braun U. 1995. A monograph of Cercosporella, Ramularia and allied genera (phytopathogenic hyphomycetes). Vol. 1. Eching: IHW-Verlag. 333 p.

- 1998. A monograph of Cercosporella, Ramularia and allied genera (phytopathogenic hyphomycetes). Vol. 2. Eching: IHW-Verlag. 493 p.

— Crous PW, Nakashima C. 2014. Cercosporoid fungi (Mycosphaerellaceae) 2. Species on monocots (Acoraceae to Xyridaceae, excluding Poaceae). IMA Fungus 5:203390, doi:10.5598/imafungus.2014.05.02.04

- — tions of Stenella species to Zasmidium. Schlechtendalia 20:99-104.

Carbone I, Kohn LM. 1999. A method for designing primer sets for speciation studies in filamentous ascomycetes. Mycologia 91:553-556, doi:10.2307/3761358

Cheewangkoon R, Crous PW, Hyde KD, Groenewald JZ, Toanan C. 2008. Species of Mycosphaerella and related anamorphs on Eucalyptus leaves from Thailand. Persoonia 21:77-91, doi:10.3767/003158508X370857

Corlett M. 1991. An annotated list of the published names in Mycosphaerella and Sphaerella. Mycol Mem 18:1-328.

Crous PW, Braun U. 2003. Mycosphaerella and its anamorphs 1. Names published in Cercospora and Passalora. Utrecht: CBS-KNAW Fungal Biodiversity Centre. 571 p.

- - Groenewald JZ. 2007. Mycosphaerella is polyphyletic. Stud Mycol 58:1-32, doi:10.3114/sim. 2007.58.01

- - - Hunter GC, Wingfield MJ, Verkley GJM, Shin H-D, Nakashima C, Groenewald JZ. 2013. Phylogenetic lineages in Pseudocercospora. Stud Mycol 75:37-114, doi:10.3114/sim0005

—, Gams W, Stalpers JA, Robert V, Stegehuis G. 2004a. MycoBank: an online initiative to launch mycology into the 21st century. Stud Mycol 50:19-22.

- Groenewald JZ, Groenewald M, Caldwell P, Braun U, Harrington TC. 2006. Species of Cercospora associated with gray leaf spot of maize. Stud Mycol 55:189-197, doi:10.3114/sim.55.1.189

—, - Mansilla JP, Hunter GC, Wingfield MJ. 2004b. Phylogenetic reassessment of Mycosphaerella spp. and their anamorphs occurring on Eucalyptus. Stud Mycol 50:195-214.

— — - Pongpanich K, Himaman W, Arzanlou M, Wingfield MJ. 2004c. Cryptic speciation and host specificity among Mycosphaerella spp. occurring on Australian Acacia species grown as exotics in the tropics. Stud Mycol 50:457-469.

— Schoch CL, Hyde KD, Wood AR, Gueidan C, de Hoog GS, Groenewald JZ. 2009a. Phylogenetic lineages in the Capnodiales. Stud Mycol 64:17-47, doi:10.3114/ sim.2009.64.02

- , Summerell BA, Carnegie AJ, Wingfield MJ, Hunter GC, Burgess TI, Andjic V, Barber PA, Groenewald JZ. 2009b. Unravelling Mycosphaerella: do you believe in genera? Persoonia 23:99-118, doi:10.3767/003158 509X479487

,-- , Mostert L, Groenewald JZ. 2008. Host specificity and speciation of Mycosphaerella and Teratosphaeria species associated with leaf spots of Proteaceae. Persoonia 20:59-86, doi:10.3767/003158508X323949

- Verkley GJM, Groenewald JZ, Samson RA. 2009c. Fungal biodiversity. CBS Laboratory Manual Series 1. Utrecht: CBS-KNAW Fungal Biodiversity Centre. 269 p.

Deng XX, Peng CJ, Chen ZS, Deng ZN, Xu JG, Li J. 2008. Citrus varieties in China. Beijing: China Agriculture Press. p 16-17, 19, 23.

Drummond AJ, Ashton B, Buxton S, Cheung M, Cooper A, Heled J, Kearse M, Moir R, Stones-Havas S, Sturrock S, Thierer T, Wilson A. 2011. Geneious 5.5. www.geneious.com

Fisher FE. 1961. Greasy spot and tar spot of citrus in Florida. Phytopathology 51:297-303.

Furuya N, Takashima M, Shiotani H. 2012. Reclassification of citrus pseudo greasy spot causal yeasts, and a proposal of two new species, Sporobolomyces productus sp. nov. and S. corallinus sp. nov. Mycoscience 53:261-269, doi:10. 1007/s10267-011-0163-y

Glass NL, Donaldson GC. 1995. Development of primer sets designed for use with the PCR to amplify conserved genes from filamentous ascomycetes. Appl Environ Microbiol 61:1323-1330.

Groenewald JZ, Nakashima C, Nishikawa J, Shin HD, Park JH, Jama AN, Groenewald M, Braun U, Crous PW. 2013. Species concepts in Cercospora: spotting the weeds among the roses. Stud Mycol 75:115-170, doi:10.3114/ $\operatorname{sim} 0012$

Gueidan C, Roux C, Lutzoni F, 2007. Using multigene phylogeny analysis to assess generic delineation and character evolution in Verrucariaceae (Verrucariales, Ascomycota). Mycol Res 111:1145-1168, doi:10.1016/j.mycres.2007. 08.010

Haggag WM. 2012. First report of Mycosphaerella citri, the agent of greasy spot of orange in Egypt. J Plant Pathol 94:92 (supplement), doi:10.4454/JPP.V95I4 SUP.022

Hillis DM, Bull JJ. 1993. An empirical test of bootstrapping as a method for assessing confidence in phylogenetic analysis. Syst Biol 42:182-192, doi:10.1093/sysbio/ 42.2.182

Huang L. 1943. The diseases of Citrus spp. of Guangxi (in Chinese). Guangxi Nong Xun 4:27-61.

Hunter GC, Wingfield BD, Crous PW, Wingfield MJ. 2006. A multigene phylogeny for species of Mycosphaerella 
occurring on Eucalyptus leaves. Stud Mycol 55:147-161, doi:10.3114/sim.55.1.147

Jiang LY, Xu FS, Yu HM. 2012. The reports of disease symptoms and field epidemiology of citrus yellow spot (in Chinese). J Zhejiang Agric Sci 7:1011-1013.

Katoh K, Toh H. 2010. Parallelization of the MAFFT multiple sequence alignment program. Bioinformatics 26:18991900, doi:10.1093/bioinformatics/btq224

Koizumi M. 1986. Sporobolomyces roseus, a causal agent of citrus pseudo greasy spot (Nise-ohan-byo) and the infection process of disease. Ann Phytopathol Soc Japan 52: $758-765$.

Marcó GM, Whiteside JO. 1986. A disease similar to greasy spot but of unknown etiology on citrus leaves in Argentina. Plant Dis 70:1074, doi:10.1094/PD-70-1074a

Mason-Gamer RJ, Kellogg EA. 1996. Testing for phylogenetic conflict among molecular datasets in the tribe Triticeae (Gramineae). Syst Biol 45:524-545, doi:10.1093/sysbio/ 45.4.524

Maxwell A, Jackson SL, Dell B, Hardy GES. 2005. PCR identification of Mycosphaerella species associated with leaf diseases of Eucalyptus. Mycol Res 109:992-1004, doi:10. 1017/S0953756205003539

Mondal SN, Howd DS, Brlansky RH, Timmer LW. 2004. Mating and pseudothecial development in Mycosphaerella citri, the cause of citrus greasy spot. Phytopathology 94:978-982, doi:10.1094/PHYTO.2004.94.9.978

O’Donnell K, Cigelnik E. 1997. Two divergent intragenomic rDNA ITS2 types within a monophyletic lineage of the fungus Fusarium are nonorthologous. Mol Phylogenet Evol 7:103-116.

-, Kistler HC, Cigelnik E, Ploetz RC. 1998. Multiple evolutionary origins of the fungus causing Panama disease of banana: concordant evidence fromnuclear and mitochondrial gene genealogies. Proc Natl Acad Sci USA 95:2044-2049, doi:10.1073/pnas.95.5.2044

Perez CA, Wingfield MJ, Altier N, Blanchette RA. 2013. Species of Mycosphaerellaceae and Teratosphaeriaceae on native Myrtaceae in Uruguay: evidence of fungal host jumps. Fungal Biol 117:94-102, doi:10.1016/j.funbio.2012. 12.002

Pretorius MC, Crous PW, Groenewald JZ, Braun U. 2003. Phylogeny of some cercosporoid fungi from Citrus. Sydowia 55:286-305.

Quaedvlieg W, Binder M, Groenewald JZ, Summerell BA, Carnegie AJ, Burgess TI, Crous PW. 2014. Introducing the consolidated species concept to resolve species in the Teratosphaeriaceae. Persoonia 33:1-40, doi:10.3767/ 003158514 X681981

_, Groenewald JZ, de Jesús Yáñez-Morales M, Crous PW. 2012. DNA barcoding of Mycosphaerella species of quarantine importance to Europe. Persoonia 29:101115, doi:10.3767/003158512X661282

-, Kema GHJ, Groenewald JZ, Verkley GJM, Seifbarghi S, Razavi M, Gohari AM, Mehrabi R, Crous PW. 2011. Zymoseptoria gen. nov.: a new genus to accommodate Septoria-like species occurring on graminicolous hosts. Persoonia 26:57-69, doi: 10.3767/003158511X 571841
, Verkley GJM, Shin HD, Barreto RW, Alfenas AC, Swart WJ, Groenewald JZ, Crous PW. 2013. Sizing up Septoria. Stud Mycol 75:307-390, doi:10.3114/sim0017

Rayner RW. 1970. A mycological color chart. Surrey: Commonwealth Mycological Institute and British Mycological Society. 34 p.

Seif AA. 2000. Phaeoramularia fruit and leaf spot. In: Timmer LW, Garnsey SM, Graham JH, eds. Compendium of Citrus diseases. St Paul, Minnesota: APS Press. p 29-30.

Sivanesan A. 1984. The bitunicate Ascomycetes and their anamorphs. Vaduz: J. Cramer. 701 p.

Smith H, Wingfield MJ, Crous PW, Coutinho TA. 1996. Sphaeropsis sapinea and Botryosphaeria dothidea endophytic in Pinus spp. and Eucalyptus spp. in South Africa. $S$ Afr J Bot 62:86-88, doi:10.1016/S0254-6299(15) 30596-2

Stukenbrock EH, Quaedvlieg W, Javan-Nikhah M, Zala M, Crous PW, McDonald BA. 2012. Zymoseptoria ardabiliae and Z. pseudotritici, two progenitor species of the septoria tritici leaf blotch fungus Z. tritici (synonym: Mycosphaerella graminicola). Mycologia 104:1397-1407, doi:10. 3852/11-374

Swofford DL. 2003. PAUP* 4.0b10: phylogenetic analysis using parsimony (*and other methods). Sunderland, Massachusetts: Sinauer Associates.

Tanaka S, Yamada S. 1952. Studies on the greasy spot (black melanose) of citrus I. Confirmation of the causal fungus and its taxonomic study (English summary). Bull TokaiKinki Natl Agric Exp Station 1:1-15.

Timmer LW, Gottwald TR. 2000. Greasy spot and similar diseases. In: Timmer LW, Garnsey SM, Graham JH, eds. Compendium of Citrus diseases. St Paul, Minnesota: APS Press. p 25-28.

, Roberts PD, Darhower HM, Bushong PM, Stover EW, Peever TL, Ibáñez AM. 2000. Epidemiology and control of citrus greasy spot in different citrus-growing areas in Florida. Plant Dis 84:1294-1298, doi:10.1094/PDIS. 2000.84.12.1294

Verkley GJM, Quaedvlieg W, Shin HD, Crous PW. 2013. A new approach to species delimitation in Septoria. Stud Mycol 75:213-305, doi:10.3114/sim0018

Videira SIR, Groenewald JZ, Kolecka A, van Haren L, Boekhout T, Crous PW. 2015. Elucidating the Ramularia eucalypti species complex. Persoonia 34:50-64, doi:10.3767/ 003158515X685670

Vilgalys R, Hester M. 1990. Rapid genetic identification and mapping of enzymatically amplified ribosomal DNA from several Cryptococcus species. J Bacteriol 172: 4238-4246.

Wang XH, Chen GQ, Huang F, Zhang JZ, Hyde KD, Li HY. 2012. Phyllosticta species associated with citrus diseases in China. Fungal Divers 52:209-224, doi:10.1007/ s13225-011-0140-y

White TJ, Bruns T, Lee S, Taylor J. 1990. Amplification and direct sequencing of fungal ribosomal RNA genes for phylogenetics. In: Innis MA, Gelfand DH, Sninsky JJ, White TJ, eds. PCR protocols: a guide to methods and applications. New York: Academic Press. p 315-322. 
Whiteside JO. 1972. Histopathology of Citrus greasy spot and identification of the causal fungus. Phytopathology 62:260-263, doi:10.1094/Phyto-62-260

Yan SX. 1984. The study of citrus yellow spot occurrence and control (in Chinese). Zhejiang Ganju 1-2:62-66.
Zhang FR, Yin GY. 1987. The fungus causing greasy yellow spot of citrus in China (in Chinese). Acta Phytopathol Sin 17:153-159.

Zhou KL, Ye YM. 2010. The record of fruit trees in China: Citrus (in Chinese). Beijing: China Forestry Press. p 4-5. 